\title{
Study on Dynamic of Phytoplankton in the Southern Part of Caspian Sea
}

\author{
Tahami FS* \\ Agricultural Research, Education \& Extension Organization, Iran
}

Submission: February 12, 2017; Published: March 27, 2017

*Corresponding author: Tahami FS, Agricultural Research, Education \& Extension Organization, Iranian Fisheries Research OrganizationCaspian Sea Ecology Research Center, Iran, Email: farnaz_tahami@yahoo.com

\begin{abstract}
Due to various Physic and Chemical factors of rivers leading to the sea, the situation seems different topography Throughput rate initial production in the different seasons are different. During 2012 in spring, summer, autumn and winter, in a study of 8 transects of 40 stations. In each transect from Astara to the Turkmen. 5 stations at depths of $5.10 .20 .50 .100 \mathrm{~m}$ were selected for sampling. The total number of 182 species from seven branches Bacillariophyta, Pyrrophyta, Cyanophyta, Chlorophyta, Euglenophyta, Xantophyta and Chrysophyta phytoplankton were identified. Including 81 species of Bacillariophyta, 33 Cyanophyta, 25 Pyrrophyta, 31 Chlorophyta, 9 Euglenophyta, 1 Xantophyta and Chrysophyta had 1 specie. Our study demonstrates that across Southern Caspian Sea, varying in environmental conditions and morphology, pronounced season and temperature gradients favor the distribution of bulk phytoplankton into more defined layers and seasons, while the depth of the peak and the heterogeneity of individual phytoplankton groups were differentially affected by habitat structure.
\end{abstract}

Keywords: Phytoplankton; Caspian sea; Dynamic; Diversity; Species

\section{Introduction}

Since phytoplankton are the base of life and productivity of aquatic ecosystems, sustainable ecological study of the Caspian Sea, particularly the distribution and identification of species composition, density and biomass, seasonal and regional variations in phytoplankton before each study seems necessary [1]. Due to various circumstances physical and chemical rivers leading to the sea, seabed topography in different situation appears to be of primary production in the eastern and western between the Caspian Sea in the season, may be altered. Identifying species and determining the distribution and biomass of the changes and how they are affected by environmental changes [2] and we are environmentally conscious [3]. We also compare the current situation with previous studies; we find that the number and types of plankton biomass have been what it is. During 2012 in spring, summer, autumn and winter, in a study of 8 transects of 40 stations. In each transect from Astara to the Turkmen. 5 stations at depths of 5. 10. 20.50. $100 \mathrm{~m}$ were selected for sampling by Niskin sampler [4] (Figure 1).

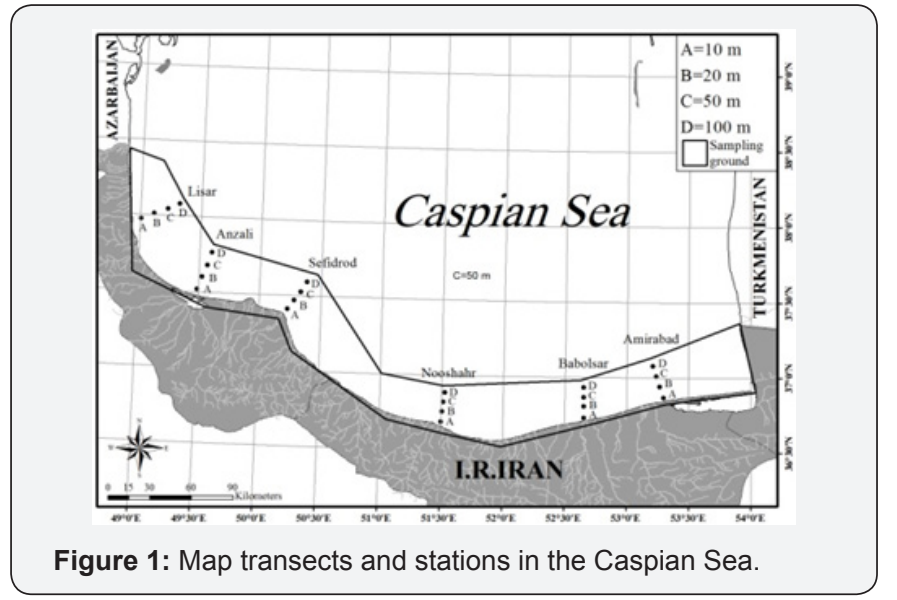

\section{Discussion}

The total number of 182 species from seven branches Bacillariophyta, Pyrrophyta, Cyanophyta, Chlorophyta, Euglenophyta, Xantophyta and Chrysophyta phytoplankton 
were identified [5]. Including 81 species of Bacillariophyta, 33 Cyanophyta, 25 Pyrrophyta, 31Chlorophyta, 9 Euglenophyta, 1 Xantophyta and Chrysophyta had 1 specie.

Studies have shown that density and biomass of Bacillariophyta were $228( \pm 471)$ per cubic meter $\left.\times 10^{6}\right)$ and $6157( \pm 290 \mathrm{mg}$ per cubic meter) respectively and Pyrrophyta were $28.17\left( \pm 27.14\right.$ ) cubic meter $\times 10^{6}$ in cubic meters) and 3349 $( \pm 336 \mathrm{mg}$ per cubic meter) and Cyanophyta $120.40( \pm 123.87$ ( per cubic meter $\times 10^{6}$ per cubic meter), biomass $(55 \pm 57 \mathrm{mg}$ per cubic meter) were the branches of the dominant phytoplankton. Abundance and biomass in different seasons have been significant differences $(p<0.05)[6,7]$. Most of Bacillariophyta (61 species) was in autumn and then in winter ( 48 species). Dominant species of Bacillariophyta were Pseudonitzschia seriata, Rhizosolenia fragilissima, Stephanodiscos sp., Melosira varians, Nitzschia acicularis and Cyclotella menenghiniana Pyrrophyta was greatest diversity of branches in summer, autumn and winter (19 species), which includes Exuviaella cordata, Exuviaella marina, Prorocentrum praximum and Prorocentrum scutllum. In the autumn density of Cyanophyta was $285.7( \pm 137.1)$ cubic meters $\times 10^{6}$ and biomass was $95 \pm 54 \mathrm{mg}$ per cubic meter and 18 species were observed. The dominant species in this category were Oscillatoria sp., Nodularia spumigena and Oscillatoria agardhii [8].

Most species of Chlorophyta branche in autumn and winter and summer median region with the highest density [9] at the density of $26.2 \%$ and most of it is Binuclearia lauterbornii. Identified as the branches Euglenophyta were Trachelomonas, Euglena and Phacus that were observed in all seasons. In winter, the highest mean biomass was $9 \pm 0.818 \mathrm{mg}$ per cubic meter and the highest density of in summer was $(0.5 \pm 0.5)$ in cubic meters $\times 10^{6}$. In winter the depth of 10 meters and surface of Babolsar, Amir Abad and Anzali, a kind of Chrysophyta and in surface of Tonekabon and Anzali a species of Xantophyta were observed that had negligible density and biomass.

\section{Conclusion}

The biological survey in each ecosystem has an important role that relate to the amount of aquatic source [10] there. The study of phytoplankton is essential that helps us to achieve our goal and to indicate primary production, as algae play an important role in aquatic water bodies [5]. Our study demonstrates that across Southern Caspian Sea, varying in environmental conditions and morphology, pronounced season and temperature gradients favor the distribution of bulk phytoplankton into more defined layers and seasons, while the depth of the peak and the heterogeneity of individual phytoplankton groups were differentially affected by habitat structure. Phytoplankton habitat structure was relatively different between the different seasons [11].

\section{Acknowledgement}

Praise is to Almighty ALLAH. Lord of all creations, for his heavenly, luxurious blessing over me throughout my life and the period of this study and a very special acknowledgement is given to staff of the Caspian Sea Ecological Institute.

\section{References}

1. Khenari GA, Wan Maznah WO, Yahya K, Najafpour S, Najafpour GD, et al. (2010) Seasonal Succession of Phytoplankton Community Structure in the Southern Part of Caspian Sea American-Eurasian. J Agric Environ Sci 8(2): 146-155

2. Balch WM (1981) An apparent lunar tidal cycle of phytoplankton blooming and community succession in the Gulf of Maine. Journal of Experimental Marine Biology and Ecology 55(1): 65-77.

3. Hsiao SIC (1980) Quantitative composition, distribution, community structure and standing stock of sea ice microalgae in the Canadian Arctic. Arctic 33(4): 768-793.

4. APHA (American Public Health Association), AWWA (American Water Works Association), WPCF (Water Environment Federation) (2005) Standard Methods for the Examination of Water and Wastewater. $\left(17^{\text {th }}\right.$ edn), Washington DC, USA, p. 150 .

5. Boyd CE, Tucker CS, (1998) Pond Aquaculture Water Quality Management. Kluwer Academic Publisher, London, UK.

6. Tahami FS, Mazlan Bin AG, Negarestan H, Lotfi BWM (2011) Abundance and Biomass of Phytoplanktons in Different Seasons in Southern Caspian Sea Before and After Mnemiopsis leidyi. International Congress on Applied Biology, Mashhad, Iran.

7. Tahami FS, Mazlan AG, Negarestan H, Najafpour Sh, Lotfi WWM, et al. (2012) Phytoplankton Combination in the Southern Part of Caspian Sea. World Applied Sciences Journal 16 (1): 99-105.

8. Cullen JJ, Horrigan SG (1981) Effects of nitrate on the diurnal vertical migration, carbon to nitrogen ratio, and the photosynthetic capacity of dinoflagellate Gyrnnodiniurn splendens. Marine Biology 6231-6289.

9. Demers S, Legendre L, Therriault JC (1986) Phytodistribution of phytoplankton.

10. Battish SK (1992) Fresh water zooplanktons Of India, Oxford and IBH Publishing, New Delhi, India.

11. CEP (2001) Caspian Environmental Program, Mnemiopsis workshop, Baku, Azerbaijan. 


\section{Your next submission with Juniper Publishers will reach you the below assets}

- Quality Editorial service

- Swift Peer Review

- Reprints availability

- E-prints Service

- Manuscript Podcast for convenient understanding

- Global attainment for your research

- Manuscript accessibility in different formats ( Pdf, E-pub, Full Text, Audio)

- Unceasing customer service

Track the below URL for one-step submission https://juniperpublishers.com/online-submission.php 